which make the mountains a home. The well-being of the environment becomes close to the heart of any dweller of the wilderness and the threat of nature taking a turn for the worst can send dwellers of the backwoods to worry over their personal charge, the nature and landscape around them. Sustained inclement weather, freak storms, too much snow in a season, frost at the wrong time, drought in the wrong season or prolonged drought in any season, are all causes for worry but a natural disaster like a wildfire is feared above all. Though the title tells us only of one dramatic event in the history of her lake, cabins and near environment, the reader is drawn into her whole lifestyle of protecting, nurturing and living within the environment which she has come to call home.

As the story unfolds, Czajkowski leads us into her world, travelling long distances, keeping up with modern technology, camping and hiking with her tourist helpers. She is home in her particular isolated part of the world a long way from her nearest neighbours but connected with them by regular radio conversations, listening to radio broadcasts and occasionally eavesdropping on her neighbours' conversations, and finally email as that technology became available. At the same time, she is host to the world by operating a small guest house for people willing to travel the distance to spend a few days with her, or international wanderers who pay by passing a few weeks working and helping her with projects.

Finally the reader is led to the hot dry summer of 2004 and the devastating fire, the Lonesome Lake Fire which was well reported to the Canadian public as one of many fires in a hot dry summer, but to people of

\section{YOUNG NATURALISTS}

\section{Tale of a Great White Fish}

By Maggie de Vries. Greystone Books, Douglas \& McIntyre Publishing Group, Vancouver, British Columbia, Canada. 34 pages. $\$ 12.95$.

The book Tale of a Great White Fish follows the story of a giant white sturgeon. Through its long life, the sturgeon overcomes many obstacles in its battle to survive and reproduce. The story deals with the interaction between sturgeons and people, along the way providing the reader with a wealth of information and insight into the natural history of the sturgeon.

The story starts in 1828, when the sturgeon, named "Big Fish," was a small and defenceless egg hatched in the Fraser River. She matures into a larva and then into a fry. As a fry she must eat thousands of other small water creatures to grow. Fry are also especially vulnerable to predators, and most of the young fry never reach adulthood. The fry that survive mature into adults before returning to their spawning ground to lay their own eggs.

There are many dangers that the sturgeon must overcome. For most of their long existence sturgeon have that remote region, a disaster which shaped their environment for years to come. The reader is invited to travel with Czajkowski through the fear and uncertainty of watching gathering smoke and distressing news from various watchers in neighbouring valleys. We are inspired to evacuate with her to safer areas, but without any assurance that home or lifestyle could be preserved. Czajkowski leads us along her tale with interesting anecdotes and humorous stories about her dogs, friends, and people who come to visit her. She is an engaging story-teller and keeps the reader's attention for hours or just a few minutes at a time as the book is filled with short stories, portions of her diary and longer accounts of specific incidents.

The story builds in an entertaining way through her history of building the cabins, receiving visitors, including facts about making one's life in the wilderness at the same time maintaining connections firmly planted in the outside world. The fire is the high point of the book and gets the reader to the excitement of living her experience of the fear, doubt, loneliness and response of care for her own animals and the natural dwellers of her wilderness world. The reader enters into the story with her and can live the excitement she feels. In our sheltered world, our decisions are not always the same as the author's but she puts her concern and care for her environment in front of the reader and shows us a different world to enjoy for a little while then look forward, like her globe-trotting visitors, to the next visit we might have with her.

JIM O’NEILL

28718 Five Mile Road, Livonia, Michigan 48154 USA

been around since the time of the dinosaurs, the threats have been natural: predators, natural calamities and disease. Today, human fishermen and the caviar industry are one of the greatest perils. Big Fish was hooked by a fisherman, but fortunately she was freed by some young boys and was able to escape. During the Hells Gate Slide in 1913 many migrating sturgeon were killed. Big Fish survived, but she was forced to find a new place to spawn. Later, Big Fish had to find a new home because the lake she was living in was drained. Later still, an unknown disease swept through the Fraser River and many sturgeon died and were washed up on the shores of the lake. When the story closes, almost a hundred years later, Big Fish is still surviving, but continues to face many challenges.

Scientists study sturgeons to help them survive. They keep track of their weight and size, and try to stop overfishing. There are now laws which prevent the fishing of these magnificent animals.

The book is written as a story and at the end there is a useful list of sturgeon facts, a labelled diagram of a 
White Sturgeon, a glossary, and a letter from Rick Hansen, a famous Canadian para-athlete. Rick Hansen is the chairman of the Fraser River Sturgeon Conservation Society. The drawings by Renné Benoit are done in water colours and they provide a magnificent glimpse into the beautiful and dangerous world of the great White Sturgeon.

The book is very informative. In it, the reader will learn a great deal about the White Sturgeon's environment and behavior and appearance. The Sturgeon Facts and a glossary at the book of the book provide

\section{New TitLes}

Prepared by Roy John

$\dagger$ Available for review * Assigned

\section{ZoOLOGY}

Bird - The Definitive Visual Guide. Edited by Peter Frances et al. 2007. Dorling Kindersley, DK Enquiries, Tourmaline Editions Inc., 662 King Street West, Suite 304, Toronto, Ontario, M5V 1M7. 512 pages. GBP 25.99 Cloth.

The Black Bear Almanac. By David Smith. 2007. Globe Pequot Press, 246 Goose Lane, P.O. Box 480, Guilford, Connecticut 06437 USA. 288 pages. U.S.\$29.95.

* The Clements Checklist of Birds of the World $\left(6^{\text {th }}\right.$ edition). By James F. Clements. 2007. Cornell University Press, Sage House, 512 East State Street, Ithaca, New York 14850 USA. 864 pages. U.S.\$59.95 Cloth.

The Biology of African Savannahs. By Bryan Shorrocks. 2007. Oxford University Press, New York, New York. 268 pages. GBP 27.50 Paper.

Arctic Flight - Adventures Amongst Northern Birds. 2007. James McCallum. Langford Press, 10 New Road, Langtoft Peterborough, UK. 180 pages. GBP 37.99 Cloth.

Endangered. By George C. McGavin. 2007. Cassell Illustrated, 2-4 Heron Quays, London E14 4JP. 192 pages. U.S.\$35.

* Birds of Europe, Russia, China, and Japan: Passerines: Tyrant Flycatchers to Buntings. By Norman Arlott. 2007. Princeton University Press, 41 William Street, Princeton, New Jersey 08540 USA. 240 pages. U.S.\$29.95 Paper.

Feathers: Identification for Bird Conservation. By Marian Cieślak and Bolesław Dul. 2007. Natura Publishing House, ul. Olbrachta 118c/20, 01-373 Warszawa, Poland. 320 pages. GBP 25.62

Forensic Entomology: An Introduction. By Dorothy Gennard. 2007. John Wiley \& Sons Canada Ltd., 6045 Freemont Boulevard, Mississauga, Ontario L5R 4J3 Canada. 244 pages. U.S.\$55 Cloth.

Homalopsid Snakes, Evolution in the Mud. By J. Murphy. 2007. Krieger Publishing, P.O. Box 9542, Melbourne, Florida 32902-9542 USA. 260 pages. U.S.\$68.50 Cloth.

The Inner Bird - Anatomy and Evolution. By G. Kaiser. 2007. The University of Washington Press, P.O. Box 50096, Seattle, Washington $98145-5096$ USA. 464 pages. U.S.\$85 Cloth.

Insects of Britain and Western Europe. By Michael Chinery. 2007. A \& C Black Publishers Ltd. (United Kingdom), 37 Soho Square, London, W1D 3QZ. 320 pages. GBP 14.99 Paper. a very useful summary, and is well presented.

The book is aimed at a child's reading level. Older readers would find this book less interesting; however, it provides a basic insight into the world of a great white fish and is nicely illustrated. This book is recommended for any child with an interest in the outdoors and in nature.

JESSICA GAWN

c/o Mission of Canada, 5 Avenue de l'Arianna, Geneva 1202, Switzerland

Insect Conservation Biology. Edited by A. J. A. Stewart, T. R. New and O. T. Lewis. 2007. Oxford University Press, 198 Madison Avenue, New York, New York 10016 USA. 480 pages. U.S.\$190 Cloth.

Australia's Mammal Extinctions. By Chris Johnson. 2007. Cambridge University Press, 40 West $20^{\text {th }}$ Street, New York, New York 10011-4221 USA. 278 pages. GBP 34.99 Paper.

Owls of the United States and Canada. By W. Lynch. The University of Washington Press, P.O. Box 50096, Seattle, Washington $98145-5096$ USA. 256 pages. U.S.\$44.95 Cloth.

Spotted Owls. By J. Hobbs. 2007. Greystone Books, Suite 201, Quebec Street, Vancouver, British Columbia V5T 4S7 Canada. 144 pages. \$39.95 Cloth.

Birds of Pakistan. By Richard Grimmett and Tim Inskipp. 2007. Helm Field Guides. 256 pages. GBP 24.99 Paper.

Birds of Peru. By Daniel F. Lane, John P. O’Neill, Theodore A. Parker III, Thomas S. Schulenberg, and Douglas F. Stotz. 2007. Helm Field Guides. 656 pages. GBP 29.99 Paper.

Raptors: A Field Guide to Survey and Monitoring. By J. Hardey, H. Crick, C. Wernham, H. Riley, B. Etheridge and D. Thompson. Stationery Office (TSO), 71 Lothian Road, Edinburgh EH3 9A2 UK. Scotland. 300 pages. email: esupport@ tso.co.uk

* Reptiles and Amphibians of Canada. By Chris Fisher and Ronald Brooks. 2007. Lone Pine Publishing, 10145 - 81 Avenue, Edmonton, Alberta T6E 1W9 Canada. 208 pages. $\$ 18.95$.

* Rodent Societies. By J. Wolff and P. Sherman (Eds). 2007. University of Chicago Press, 1427 East $60^{\text {th }}$ Street, Chicago, Illinois 60637 USA. 610 pages. U.S.\$49 Paper, \$125 Cloth.

The New Encyclopaedia of Snakes. By Christopher Mattison. 2007. Cassell Illustrated, 2-4 Heron Quays, London E14 4JP. 272 pages. GBP 30 Cloth.

Native Trees of the Southeast - An Identification Guide. By L. Katherine Kirkman, Claud L. Brown, and Donald J. Leopold. 2007. Timber Press, 133 SW 2nd Avenue, Suite 450, Portland, Oregon 97204 USA. 372 pages. \$45.95.

Waterbirds Around the World. By Gerard Boere, Colin Galbraith and David Stroud [Editors]. 2007. TSO (The Stationery Office), 71 Lothian Road, Edinburgh EH3 9A2 UK. Scotland. 940 pages. GBP 50. 